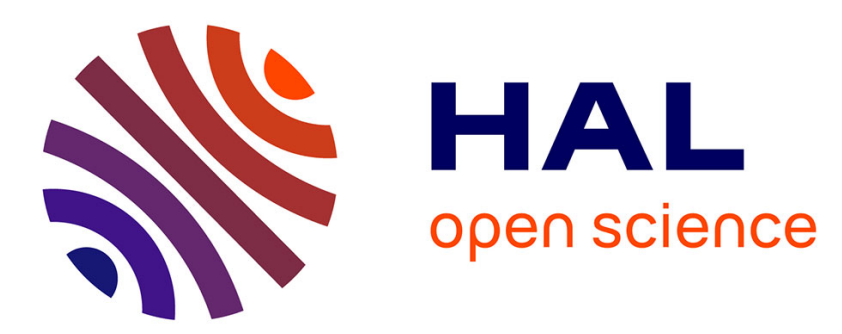

\title{
The spatial dynamics of diversity in Centridini bees: the abundance of oil-producing flowers as a measure of habitat quality
}

\author{
Jaqueline Rosa, Mauro Ramalho
}

\section{- To cite this version:}

Jaqueline Rosa, Mauro Ramalho. The spatial dynamics of diversity in Centridini bees: the abundance of oil-producing flowers as a measure of habitat quality. Apidologie, 2011, 42 (5), pp.669-678. $10.1007 / \mathrm{s} 13592-011-0075-\mathrm{z}$. hal-01003612

\section{HAL Id: hal-01003612 https://hal.science/hal-01003612}

Submitted on 1 Jan 2011

HAL is a multi-disciplinary open access archive for the deposit and dissemination of scientific research documents, whether they are published or not. The documents may come from teaching and research institutions in France or abroad, or from public or private research centers.
L'archive ouverte pluridisciplinaire HAL, est destinée au dépôt et à la diffusion de documents scientifiques de niveau recherche, publiés ou non, émanant des établissements d'enseignement et de recherche français ou étrangers, des laboratoires publics ou privés. 


\title{
The spatial dynamics of diversity in Centridini bees: the abundance of oil-producing flowers as a measure of habitat quality
}

\author{
Jaqueline Figuerêdo Rosa ${ }^{1}$, Mauro Ramalho ${ }^{2}$ \\ ${ }^{1}$ Departamento de Professores, Instituto Federal de Educação, Ciência e Tecnologia Baiano, Instituto Federal de \\ Educação, Ciência e Tecnologia Baiano, Campus Guanambi. Distrito de Ceraíma, Post Office Box 9, 46430000, \\ Guanambi, Bahia, Brazil \\ ${ }^{2}$ Laboratório de Ecologia da Polinização (ECOPOL), Instituto de Biologia, Universidade Federal da Bahia, Rua \\ Barão de Jeremoabo, s/n Ondina, 40170115, Salvador, Bahia, Brazil
}

Received 25 August 2010 - Revised 31 January 2011 - Accepted 7 February 2011

\begin{abstract}
It is assumed that oil bees in the tribe Centridini and oil flowers in the family Malpighiaceae have a conservative evolutionary association, and it is postulated that they also have a tight ecological relationship. Here, we test the hypothesis that variations in the availability of Malpighiaceae flowers affect the abundance and richness of centridine bees. We measured oil availability and sampled bees on oil flowers of Byrsonima sericea DC. (Malpighiaceae) in 12 localities (habitats), along the Northeastern Brazilian Atlantic coast. The availability of floral oil was strongly correlated with richness and abundance of centridine bees. In contrast, no significant correlation was observed between abundance and richness of centridine bees after excluding the effect of oil abundance. We proposed that the asymmetry of density dependence is determining the observed pattern of regional diversity for centridine bees.
\end{abstract}

bee diversity / Centridini / floral oil / habitat quality / Malpighiaceae

\section{INTRODUCTION}

Flowers of few plant families produce floral oil, and only a few specialized bee groups collect and use this resource to feed their larvae and to build and protect their nests, creating a narrow association between these plants and the specialized oil bee groups that exploit them (Simpson and Neff 1981; Buchmann 1987; Vogel 1990; Steiner and Whitehead 2002; Renner and Schaefer 2010). Fossil records support the hypothesis that there is a very early association between oil-producing Malpighiaceae and centridine bees, beginning

Corresponding author: J.F. Rosa, jaquefrosa@gmail.com

Manuscript editor: Marla Spivak shortly after the appearance of both in northern South America (e.g., Neff and Simpson 1981; Taylor and Crepet 1987; Vogel 1990; Davis et al. 2002), and a subsequent long history of conservative evolutionary interactions between the two groups (Anderson 1979; Neff and Simpson 1981; Vogel 1990; Renner and Schaefer 2010). Bees in the tribe Centridini (Apidae) are adapted to harvest oil from epithelial elaiophores, particularly from flowers in the family Malpighiaceae that comprise approximately $80 \%$ of the regional oil-flower species (Anderson 1979; Joly 1977; Neff and Simpson 1981; Buchmann 1987; Vogel 1990; Davis et al. 2002; Machado 2004). They are the largest oil-collecting bee group and are restricted to the neotropics (Vogel 1990; Silveira et al. 2002; Machado 2004). In parallel, only the 
American lineages of Malpighiaceae have developed epithelial elaiophores (Buchmann 1987).

Recent field surveys in several vegetation types in the Brazilian tropics support the hypothesis that centridine bees are frequent and abundant visitors of Malpighiaceae flowers (Ramalho and Silva 2002; Machado 2004). As a rule, these oil bees are also the most effective and efficient pollinators of Malpighiaceae species (e.g., Raw 1979; Barros 1992; Freitas et al. 1999; Teixeira and Machado 2000; Sigrist and Sazima 2004; Costa et al. 2006; Rêgo and Albuquerque 2006), although this tight ecological relationship is not mediated by speciesspecific interactions and each species of Centridini is often able to use several Malpighiaceae species and vice versa (Simpson and Neff 1981; Gottsberger 1986; Roubik 1989; Vogel 1990; Machado 2004). Given the long evolutionary association between these species, it is reasonable to assume a strong reciprocal influence between both groups in contemporary communities, and variations in abundance and richness in one group in this relationship are likely to have a direct effect on the other (Ramalho and Silva 2002).

For decades, ecologists have been trying to understand the relationship between the productivity of resources and the diversity of their consumers (Abrams 1988, 1995; Owen 1988; Tilman 1993; Rosenzweig and Abramsky 1993; Rosenzweig 1995; Waide et al. 1999; Mittelbach et al. 2001; Partel et al. 2007). Most of these studies pointed out that productivity may affect diversity, although different mechanisms may be involved. A major impediment to understanding the relationship between resource availability and bee community structure is that it is difficult to measure the availability of floral resources for bees within natural habitats, and consequently, few scientists have attempted to do this (Buchmann 1987).

In the present study, we test the hypothesis that the availability of floral oil from Malpighiaceae affects the abundance and richness of centridine bees. We tested this hypothesis at a regional scale by comparing 12 sites along the Northeastern Atlantic coast of Brazil. We also discuss the role of resource partitioning or asymmetric density dependence as the underlying mechanisms regulating the relationship between habitat productivity and Centridini diversity.

\section{MATERIAL AND METHODS}

\subsection{Sampling design}

We designed the study at a regional scale following the spatial categories described by Waide et al. (1999), selecting 12 sites along the Northeastern Atlantic coast of Bahia, Brazil (Table I.). The region's once contiguous forests have been cleared and fragmented to make way for agroforestry dominated by oil palm, rubber, and cacao plantations and more recently for the construction of infrastructure for a growing tourism industry. Tropical forest fragments (Atlantic Forest) still cover some of the low hills, plateaus, and lowlands. An extensive shrubby-arboreal restinga vegetation persists along the sandy coastal plain and intermingles with low secondary forest and other open disturbed vegetation, and it is mainly in these vegetation remnants that we established our plots.

We consider each of the12 sites as a sampling unit, and we evaluated the availability of floral oil and the richness and abundance of centridine bees in each one. We chose Byrsonima sericea DC. (Malpighiaceae) as the focal plant because: (1) a high diversity of Centridini species visit its oil flowers (Machado 2004), even when other oil flowers are available (e.g., Costa et al. 2006); (2) it is one of the most abundant oil flowers along the coastal plain, i.e., sand dunes and restingas (Ramalho and Silva 2002; Costa et al. 2006); (3) while common throughout, its population density varies between sites (Ramalho and Silva 2002); and (4) it is likely that oilflower abundance rather than oil-flower diversity is related to the variation in regional diversity of centridine bees (Ramalho and Silva 2002), so choosing the most abundant oil producer made logistic sense.

\subsection{Measurements of floral oil availability}

The mean and variance of floral oil availability were estimated by sampling $B$. sericea in five random quadrats of 0.2 ha $(100 \times 20 \mathrm{~m})$, in each plot. All individual plants of $B$. sericea were counted in each of the five quadrats/plot, and the quantity of floral oil was estimated by multiplying the density of individual $B$. 
Table I. Description of habitats or sampling sites $(n=12)$ in the Atlantic coast of Brazil.

\begin{tabular}{|c|c|c|c|c|c|}
\hline Abbreviation & Area (ha) & Vegetation & $\begin{array}{l}\text { Municipal } \\
\text { district }\end{array}$ & $\begin{array}{l}\text { Geographical } \\
\text { coordinate }\end{array}$ & Observation \\
\hline MSJ & 300 & $\begin{array}{l}\text { Herbaceous-shrubby } \\
\text { in sand dunes }\end{array}$ & Mata de São João & $\begin{array}{l}\text { S } 12^{\circ} 32^{\prime} 29.8^{\prime \prime} \\
\text { W } 37^{\circ} 59^{\prime} 57.6^{\prime \prime}\end{array}$ & Rural area \\
\hline $\mathrm{C} 1$ & 100 & $\begin{array}{l}\text { Herbaceous-shrubby } \\
\text { in sand dunes }\end{array}$ & Camaçari & $\begin{array}{l}\mathrm{S} 12^{\circ} 47^{\prime} 58.8^{\prime \prime} \\
\text { W } 38^{\circ} 12^{\prime} 56.1^{\prime \prime}\end{array}$ & Rural area \\
\hline $\mathrm{C} 2$ & 60 & $\begin{array}{l}\text { Shrubby-arboreal } \\
\text { in restinga }\end{array}$ & Camaçari & $\begin{array}{l}\text { S } 12^{\circ} 46^{\prime} 34.28^{\prime \prime} \\
\text { W } 38^{\circ} 19^{\prime} 4.07^{\prime \prime}\end{array}$ & Rural area \\
\hline Abaeté & 180 & $\begin{array}{l}\text { Herbaceous-shrubby } \\
\text { in sand dunes }\end{array}$ & Salvador & $\begin{array}{l}\text { S } 12^{\circ} 56^{\prime} 38.66^{\prime \prime} \\
\text { W } 38^{\circ} 21^{\prime} 32.91^{\prime \prime}\end{array}$ & Urban area \\
\hline Pituaçú & 450 & Shrubby-arboreal & Salvador & $\begin{array}{l}\text { S } 12^{\circ} 57^{\prime} 58.86^{\prime \prime} \\
\text { W } 38^{\circ} 24^{\prime} 41.88^{\prime \prime}\end{array}$ & $\begin{array}{l}\text { Parque Metropolitano } \\
\text { de Pituaçú (urban area) }\end{array}$ \\
\hline Stiep & 20 & $\begin{array}{l}\text { Herbaceous-shrubby } \\
\text { in sand dunes }\end{array}$ & Salvador & $\begin{array}{l}\text { S } 12^{\circ} 59^{\prime} 15.51^{\prime \prime} \\
\text { W } 38^{\circ} 26^{\prime} 32.71^{\prime \prime}\end{array}$ & Urban area \\
\hline UFBA & 20 & $\begin{array}{l}\text { Remainder of } \\
\text { secondary Atlantic } \\
\text { forest and gardens }\end{array}$ & Salvador & $\begin{array}{l}\mathrm{S} 13^{\circ} 0^{\prime} 16.26^{\prime \prime} \\
\mathrm{W} 38^{\circ} 30^{\prime} 39.20^{\prime \prime}\end{array}$ & $\begin{array}{l}\text { Universidade Federal } \\
\text { da Bahia (urban área) }\end{array}$ \\
\hline Ilha & 6 & $\begin{array}{l}\text { Shrubby-arboreal } \\
\text { in restinga }\end{array}$ & Itaparica & $\begin{array}{l}\text { S } 13^{\circ} 03^{\prime} 46.2^{\prime \prime} \\
\text { W } 38^{\circ} 43^{\prime} 23.8^{\prime \prime}\end{array}$ & Island of Itaparica \\
\hline Nazaré & - & $\begin{array}{l}\text { Remainder of Atlantic } \\
\text { forest in transition } \\
\text { area between } \\
\text { restinga and } \\
\text { hillside forest }\end{array}$ & Nazaré & $\begin{array}{l}\text { S } 12^{\circ} 59^{\prime} 22.6^{\prime \prime} \\
\text { W } 8^{\circ} 54^{\prime} 03.9^{\prime \prime}\end{array}$ & Rural area \\
\hline Pratigi & 32,000 & $\begin{array}{l}\text { Herbaceous-shrubby } \\
\text { in restinga }\end{array}$ & Ituberá & 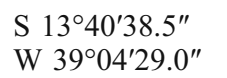 & $\begin{array}{l}\text { Área de Proteção } \\
\text { Ambiental de Pratigi }\end{array}$ \\
\hline M1 & 3 & $\begin{array}{l}\text { Gap regeneration in } \\
\text { the mosaic of } \\
\text { Atlantic forest and } \\
\text { rubber trees forestry }\end{array}$ & Ituberá & $\begin{array}{l}\text { S } 13^{\circ} 49^{\prime} 44.4^{\prime \prime} \\
\text { W } 39^{\circ} 11^{\prime} 27.9^{\prime \prime}\end{array}$ & $\begin{array}{l}\text { Plantações Michelin da } \\
\text { Bahia Ltda's property }\end{array}$ \\
\hline M2 & 4 & $\begin{array}{l}\text { Gap regeneration in } \\
\text { the mosaic of } \\
\text { Atlantic forest and } \\
\text { rubber trees forestry }\end{array}$ & Ituberá & $\begin{array}{l}\text { S } 13^{\circ} 51^{\prime} 27.8^{\prime \prime} \\
\text { W } 39^{\circ} 11^{\prime} 36.2^{\prime \prime}\end{array}$ & $\begin{array}{l}\text { Plantações Michelin da } \\
\text { Bahia Ltda's property }\end{array}$ \\
\hline
\end{tabular}

sericea plants with elaiophores by $0.128 \mathrm{~L}$ following Ramalho and Silva (2002). Within a plot and among the plots, the small trees of $B$. sericea varied between 2.0 and $4.0 \mathrm{~m}$ high. There is no evidence of large variation in oil production by flowers or in the density of flowers per plant canopy among regional habitat types (Ramalho and Silva 2002; Costa et al. 2006). Therefore, we assumed that the density of plants was a good measure of oil availability in each habitat and would be sufficient for comparisons within the order of magnitude of the variation of productivity among the habitats tested here.

We placed sampling quadrats only in sections of the plot that contained individuals of the focal plant; thus, oil availability could have been overestimated in all habitat types. In two habitat plots, it was only possible to establish and measure two quadrats due to the low occurrence of the species there (APA Lagoas e Dunas de Abaeté and the Campus of the Federal University of Bahia, UFBA).

\subsection{Measurements of the richness and abundance of centridine oil bees}

During the period of high flower production in each quadrat (from November to January: Ramalho and Silva 2002; Costa et al. 2006), centridine bees 
were sampled while visiting flowers. High flower production was qualified as the period when most of the $B$. sericea plants within the sample quadrats exhibited large quantities of flowers. These peak flowering periods lasted for 1-2 weeks and varied between November and January among the 12 plots. The bees were captured with entomological nets for 15 to $30 \mathrm{~min}$, at hour intervals, between 0800 and 1300 hours when the bees are most active foraging (Ramalho and Silva 2002). In each habitat plot, the collecting effort totaled $12 \mathrm{~h}$. However, because of variable weather conditions and the number of field assistants available (two to four persons each time), it took between 2 and 9 days to complete the sampling in each plot. The bees were identified and deposited at the Pollination Ecology Lab of the Federal University of Bahia-Brazil (ECOPOL-IBUFBA).

\subsection{Statistical analysis}

As most of the data showed a normal distribution and linear relationship, we used a linear correlation analysis (Table III). The exception was the analysis of the relationship between oil availability and Centridini richness for which we used a rarefaction analysis. When there was homoscedasticity, correlation was calculated using Pearson's coefficient; otherwise, we used Spearman's coefficient. Partial correlations were used to measure the relationship between each pair of variables, when excluding the effect of other ones (e.g., availability of floral oil, absolute abundance, and richness of centridine bees). We used SPSS 13.0 for Windows for these analyses. Rarefaction was also applied to standardize the effect of sample size on richness estimates, using the statistical package Ecological Methodology 6.1. Kolmogorov-Smirnov's statistic was used to test for normality and $F$ test to test for linearity of relationship between the variables, with the Graphpad Instat 3.05.

\section{RESULTS}

\subsection{Flower visitors of $B$. sericea DC.}

A total of 1,246 female bees belonging to eight tribes were collected on the $B$. sericea flowers: Apini, Augochlorini, Centridini, Exo- malopsini, Meliponini, Tapinotaspidini, Xylocopini, and Halictini. Among oil-collecting bees, Centridini was the dominant group (922 individuals, 73\%), followed by Tapinotaspidini (97 individuals, $8 \%$ ). Among pollen-collecting bees, the Augochlorini comprised 9\% (113 individuals) and the eusocial bees Meliponini, 7\% (93 individuals). Centridini was also the most frequent and dominant bee group in all sampling habitats (Table II) with 31 Centridini species, which include most of Centris species known from Northeastern Brazilian Atlantic Coast. Local species richness (alpha diversity) varied from 2 to 14 among the 12 sampled habitats.

\subsection{Floral oil availability}

We observed a high variability in the density of $B$. sericea among the 12 sites with estimates of floral oil availability ranging from 1.52 to 9.38 $\mathrm{Lha}^{-1}$ (Table II), i.e., an almost tenfold difference. The sample means and variance in floral oil availability were not correlated among the 12 sites ( $r=0.156, P=0.646$, Figure $1 \mathrm{a})$, and thus, it is likely that the spatial heterogeneity did not vary with habitat productivity.

\subsection{Correlation between the variables}

Centridine richness $(r=0.804, P=0.001$, Figure $2 \mathrm{a})$ and abundance $(r=0.810, P=0.001$, Figure $2 \mathrm{~b}$ ) showed a positive correlation with floral oil availability as did centridine richness estimated by rarefaction $(r=0.629, P=0.014$, Figure 2c; Tables III and IV). When the effect of abundance of centridines was excluded, the partial correlation between oil availability and richness of centridines was high and significant ( $r=0.669, P=0.012$, Figure 2d). The same happened with the partial correlation between oil availability and absolute abundance of centridines, when the effect of richness was excluded ( $r=0.682, P=0.010$, Figure $2 \mathrm{e}$ ). Finally, floral oil availability showed a positive correlation with the number of oil-collecting bee tribes $(r=0.501, P=0.049)$ and the total number of Apoidea tribes $(r=0.537, P=0.036)$. 
Table II. Availability of flower oils of B. sericea DC., richness of centridine, and abundance of bee tribes sampled on these flowers in the 12 habitats.

\begin{tabular}{|c|c|c|c|c|c|c|c|c|c|c|c|}
\hline \multirow[t]{2}{*}{ Sampling sites } & \multirow[t]{2}{*}{ Oils ( $\left.\mathrm{L} \mathrm{ha}^{-1}\right)$} & \multirow[t]{2}{*}{ R Cen } & \multirow[t]{2}{*}{$\mathrm{Ab}$ Cen } & \multicolumn{8}{|c|}{ Relative abundance $(\%)$ of apoidea bee tribes } \\
\hline & & & & Cen & Api & Aug & Exo & Mel & Tap & Xyl & Hal \\
\hline UFBA & 1.52 & 4 & 26 & 61.90 & & 38.10 & & & & & \\
\hline Abaeté & 2.05 & 2 & 76 & 100.00 & & & & & & & \\
\hline $\mathrm{C} 2$ & 3.98 & 5 & 32 & 100.00 & & & & & & & \\
\hline Ilha & 4.39 & 9 & 66 & 85.71 & & 11.69 & & & 2.60 & & \\
\hline Pituaçú & 4.8 & 8 & 45 & 97.83 & 2.17 & & & & & & \\
\hline M1 & 4.88 & 8 & 61 & 75.31 & 4.94 & 9.88 & 3.70 & 4.94 & 1.23 & & \\
\hline M2 & 5.41 & 9 & 45 & 88.24 & & 3.92 & & 7.84 & & & \\
\hline Nazaré & 6.85 & 11 & 64 & 85.33 & & 5.33 & 6.67 & 1.33 & 1.33 & & \\
\hline MSJ & 7.57 & 12 & 110 & 92.44 & & 5.88 & & & 0.84 & 0.84 & \\
\hline $\mathrm{C} 1$ & 8.11 & 10 & 124 & 100.00 & & & & & & & \\
\hline Pratigi & 8.4 & 14 & 137 & 41.14 & & 6.31 & 1.80 & 24.02 & 26.73 & & \\
\hline Stiep & 9.38 & 8 & 126 & 71.58 & & 24.21 & & 2.11 & 1.58 & & 0.53 \\
\hline
\end{tabular}

Oils flower oils, $R$ Cen richness of centridine, Ab Cen absolute abundance of centridine, Cen Centridini, Api Apini, Aug Augochlorini, Exo Exomalopisini, Mel Meliponini, Tap Tapinotaspidini, Xyl Xylocopini, Hal Halictini

Particularly in the last case, the increase in $B$. sericea density attracted other groups of pollencollecting bees to its flowers.

The variance of floral oil availability was not correlated with centridine richness $(r=0.140, P=$ 0.340 , Figure 1b). Likely, there is no effect of habitat spatial heterogeneity on diversity.

The abundance of centridine was also correlated with species richness $(r=0.608, P=0.018$, Figure 3a). However, the partial correlation between these two variables was not significant when the effect of oil availability was excluded ( $r=-0.126, P=0.356$, Figure $3 b)$. In other words, the apparent association between abundance and species richness is spurious.

In general, oil availability could explain approximately $65 \%$ (simple correlation, Table III) or $45 \%$ (partial correlation, Table IV) of the observed variation of richness and abundance of centridine bees. In contrast, oil
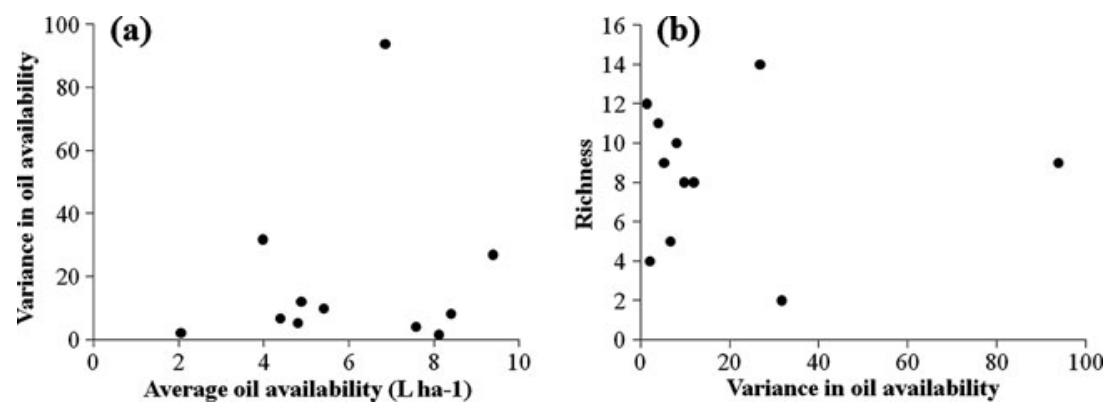

Figure 1. a Relationship between mean (liters per hectare) and variance in oil availability of B. sericea DC. among habitats; $\mathbf{b}$ relationship between variance in oil availability and richness of centridine bees. 

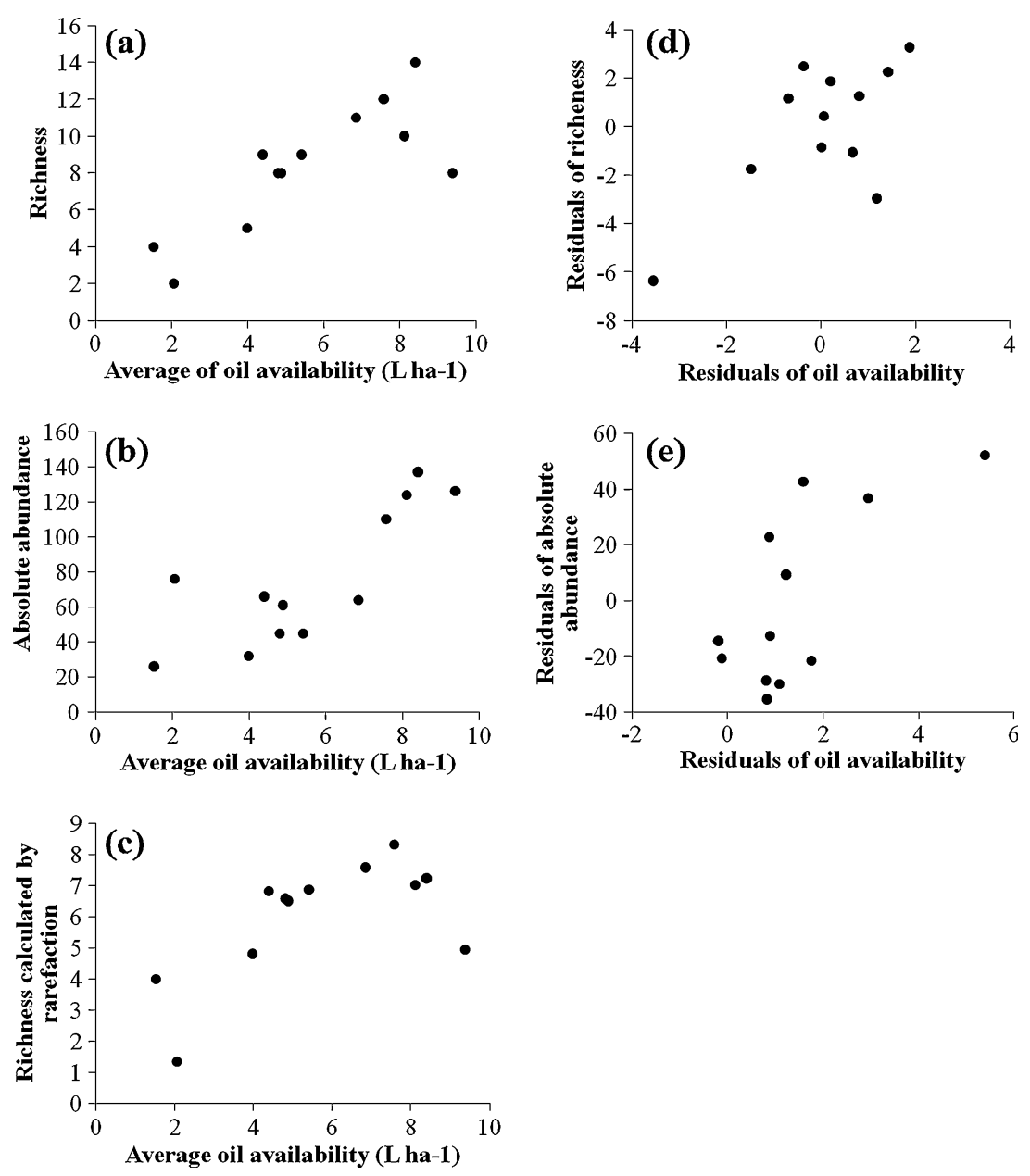

Figure 2. Correlations between availability of flower oils of $B$. sericea DC. and centridine diversity: a availability (liters per hectare) and richness; b availability (liters per hectare) and absolute abundance; c availability (liters per hectare) and richness calculated by rarefaction; $\mathbf{d}$ residuals of availability and richness; $\mathbf{e}$ residuals of availability and absolute abundance.

availability explains only $29 \%$ and $25 \%$ of the observed variations in the number of Apoidea tribes and other oil-collecting bees, respectively (Table III).

The habitat area was not correlated with centridine richness $(r=0.202, P=0.275)$, abundance of centridines $(r=0.497, P=0.060)$, and oil availability $(r=0.164, P=0.315)$. In contrast, the partial correlation between centridine richness and oil availability was significant when the effect of habitat area was excluded $(r=0.769, P=0.005)$.

\section{DISCUSSION}

\subsection{Centridini and Malpighiaceae - a tight ecological relationship}

Centridini (Apidae) was the dominant oil bee group on $B$. sericea flowers in all sampled habitats, though their relative abundance varied considerably. The females of this tribe collected mainly oil and often pollen by vibratory pollen collection (Teixeira and Machado 2000). This demonstrates the high value of $B$. sericea 
Table III. Summary of analyses of simple linear correlation.

\begin{tabular}{llllllll}
\hline Correlated variables & $r$ & $r^{2}$ & $p$ & $n$ & Coefficient & Test \\
\hline Oil availability $\times$ richness of Centridini & 0.804 & 0.646 & 0.001 & 12 & Pearson & Unilateral \\
Oil availability $\times$ absolute abundance of Centridini & 0.810 & 0.656 & 0.001 & 12 & Pearson & Unilateral \\
Absolute abundance of Centridini $\times$ richness of Centridini & 0.608 & 0.370 & 0.018 & 12 & Pearson & Unilateral \\
Oil availability $\times$ total number of apoidea tribes & 0.537 & 0.288 & 0.036 & 12 & Spearman & Unilateral \\
Oil availability $\times$ number of oil-collecting bee tribes & 0.501 & 0.251 & 0.049 & 12 & Spearman & Unilateral \\
Oil availability $\times$ Centridini richness estimated by rarefaction & 0.629 & 0.396 & 0.014 & 12 & Pearson & Unilateral \\
Average of oils availability $\times$ variance of oil availability & 0.156 & 0.024 & 0.646 & 11 & Pearson & Bilateral \\
Variance of oil availability $\times$ richness of Centridini & 0.140 & 0.020 & 0.340 & 11 & Pearson & Unilateral \\
Habitat area $\times$ richness of Centridini & 0.202 & 0.041 & 0.275 & 11 & Spearman & Unilateral \\
Habitat area $\times$ absolute abundance of Centridini & 0.497 & 0.247 & 0.060 & 11 & Spearman & Unilateral \\
Habitat area $\times$ oil availability & 0.164 & 0.027 & 0.315 & 11 & Spearman & Unilateral \\
\hline
\end{tabular}

${ }^{\text {a }}$ Richness estimated by rarefaction in subsamples of 26 individuals, in each habitat parcel

flowers as an energetic (oil) and a protein source (pollen) for centridine bees inhabiting the coastal Bahian forests.

At the regional scale, these data support the hypothesis of a tight ecological (frequent and predictable in space and time) relationship between the centridine bees and the oil flowers of B. sericea (Ramalho and Silva 2002). Therefore, it is also reasonable to infer reciprocal influences from both sides of this relationship in regional ecological communities.

\subsection{Partitioning of oil flowers by centridine bees}

The long history of conservative evolutionary interactions between Centridini and Malpighiaceae (Anderson 1979; Neff and Simpson 1981;
Vogel 1990) has also led to diffuse ecological relationships, i.e., many centridine species may explore the same Malpighiaceae host plant and vice versa (Simpson and Neff 1981; Gottsberger 1986; Vogel 1990; Machado 2004). As a result, it is likely that the partitioning of oil flowers is not a mechanism that determines the coexistence of centridine bees along the Northeastern Brazilian Atlantic coast. In contemporary communities, the abundance of floral oil may influence centridine diversity more than diversity of oil flowers (e.g., Ramalho and Silva 2002). The observed regional diversity pattern where the variation of a single Malpighiaceae oil flower (B. sericea) explains the spatial variation of centridine richness and abundance supports this hypothesis.

Table IV. Summary of analyses of partial correlation.

\begin{tabular}{|c|c|c|c|c|c|}
\hline Controlled variable & Correlated variables & $r$ & $r^{2}$ & $p$ & $n$ \\
\hline Oil availability & $\begin{array}{l}\text { Absolute abundance of Centridini } \times \text { richness } \\
\text { of Centridini }\end{array}$ & -0.126 & 0.016 & 0.356 & 12 \\
\hline $\begin{array}{l}\text { Absolute abundance } \\
\text { of Centridini }\end{array}$ & Oil availability $\times$ richness of Centridini & 0.669 & 0.448 & 0.012 & 12 \\
\hline Richness of Centridini & Oil availability $\times$ absolute abundance of Centridini & 0.682 & 0.465 & 0.010 & 12 \\
\hline Habitat area & Oil availability $\times$ richness of Centridini & 0.769 & 0.591 & 0.005 & 11 \\
\hline
\end{tabular}



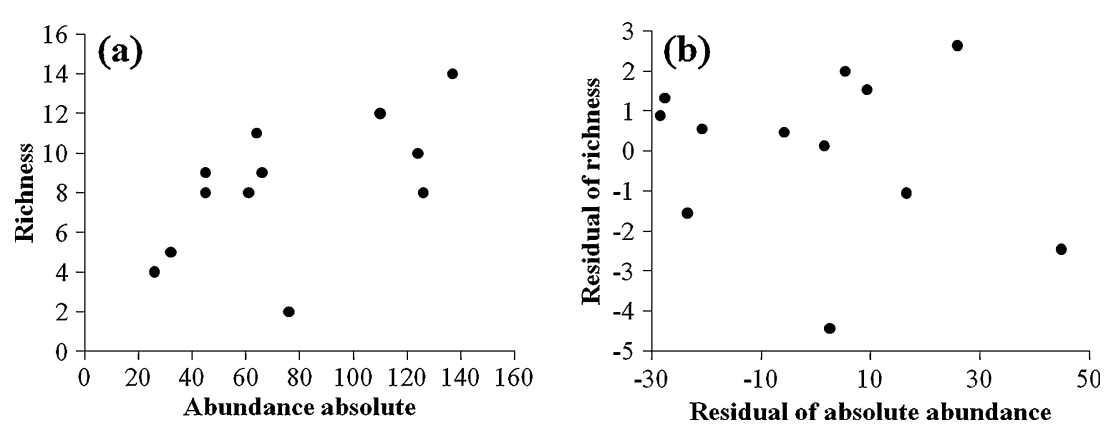

Figure 3. Correlation between absolute abundance and richness of centridine: a original values of the two variables; b partial correlation (between residuals).

\subsection{Floral oil as a measure of habitat productivity and its effect on the diversity of centridine bees}

It is frequently assumed that the relationship between habitat productivity and species diversity is unimodal (e.g., Owen 1988; Rosenzweig and Abramsky 1993; Rosenzweig 1995), although this relationship depends on several factors (Wright et al. 1993; Waide et al. 1999; Mittelbach et al. 2001; Partel et al. 2007). For instance, at a regional scale, positive linear relationships have been observed as frequently as the unimodal pattern (Waide et al. 1999; Mittelbach et al. 2001) and seem to be significantly more common in the tropics (Partel et al. 2007). This latter generalization is supported by the observed linear relationship between centridine bees and Malpighiaceae oil flowers at regional scale in the Northeastern Brazilian Atlantic coast.

At least three mechanisms could explain the positive effect of resource productivity on the coexistence of consumer species: (1) an increase in average resource availability could also increase variance and thus spatial heterogeneity, which could promote the coexistence of higher number of species through the spatial partitioning of resources (Vance 1984; Abrams 1988; Rosenzweig and Abramsky 1993; Rosenzweig 1995); (2) under high average productivity rare species would become more abundant, reducing local stochastic extinction (Rosenzweig and Abramsky 1993; Abrams 1995; Rosenzweig 1995; Adler et al. 2007); (3) and finally, with increasing productivity, asymmetric effects of density-dependence could promote species coexistence (Abrams 1983, 1988, 1995).

In fact, increases in average productivity and variance are postulated to be an underlying mechanism allowing for the coexistence of consumer species in models with more than two resources (e.g., Rosenzweig and Abramsky 1993; Tilman and Pacala 1993; Rosenzweig 1995). In this study, the increased variance in floral oil availability from a single key source (B. sericea) probably did not affect the coexistence of centridine bees and thus did not affect local diversity.

The second mechanism did not explain the observed relationship between centridine and oil flowers either. Probably, rare species are not necessarily "more abundant" and are not less exposed to stochastic extinction in productive habitats compared to unproductive habitats. Most sites with the highest oil availability have continued to be those with the greatest richness of centridine bees when the effect of centridine abundance was excluded (partial correlation).

We argue that asymmetry in density dependence offers a better explanation for the observed effect of oil availability on centridine richness. With increasing productivity, intra-specific density dependence should increase faster than interspecific density dependence (Abrams 1983, 1988, 1995; Vance 1984; Chesson 2000) and so rare species should be less extinction prone due to relaxed inter-specific competition. This could result from an increase in intra-specific competition when individuals have to exploit a very 
productive key resource that is concentrated in space and time, which is the case of oil in $B$. sericea flowers. Moreover, according to models of species coexistence at a regional scale (e.g., Slatkin 1974; Hanski 1983, 1999), the habitats with high availability of floral oil should minimize the effects of two key mechanisms: (1) the negative effect of one species on the probability of colonization by another one and (2) the positive effect of one species on the probability of extinction of another one. Finally, considering that the sites with the highest density of oil flowers actually support a higher number of centridine species, they also should be the main sources of migrants in the landscape and thus playing a key role in the spatial dynamics of centridine diversity (component $\beta$ ) along the Northeastern Brazilian Atlantic coast.

\section{ACKNOWLEDGMENTS}

We are grateful to the many people, who had helped with field sampling, especially our friends from the Pollination Ecology Lab (ECOPOL) of the Federal University of Bahia-Brazil (UFBA). We thank Dr. Favizia Freitas de Oliveira (UFBA) for helping with bees' identification. We are grateful to Dr. Cândida Maria Lima Aguiar, Dr. Claudia Maria Jacobi, and Dr. Kevin Flesher for their comments and suggestions. We thank CAPES for the grant support to the first author, $\mathrm{CNPq}$ (481113/2004-5), and FAPESB (APR0114/2006) for their financial support and to the "Plantações Michelin da Bahia Ltda." for general logistic facilities and field support.

La dynamique spatiale des abeilles Centridini: abondance des fleurs productrices d'huile comme mesure de la qualité de l'habitat

Diversité des abeilles / Centridini / huile florale / qualité de l'habitat / Malpighiaceae

Räumliche Dynamik von Diversität bei CentridiniBienen: Verfügbarkeit von ölproduzierenden Pflanzen als Maß für die Qualität des Lebensraums

Diversität der Bienen / Centridini / Florale Öle / Lebensraumqulität / Malpighiaceae

\section{REFERENCES}

Abrams, P. (1983) The theory of limiting similarity. Annu. Rev. Ecol. Syst. 14, 359-376

Abrams, P. (1988) Resource productivity-consumer species diversity: simple models of competition in spatially heterogeneous environments. Ecology 69, 1418-1433

Abrams, P. (1995) Monotonic or unimodal diversityproductivity gradients: what does competition theory predict? Ecology 76, 2019-2027

Adler, P.B., HilleRisLambers, J., Levine, J.M. (2007) A niche for neutrality. Ecol. Lett. 10, 95-104

Anderson, W.R. (1979) Floral conservatism in neotropical Malpighiaceae. Biotropica 11, 219-223

Barros, M.A.G. (1992) Fenologia da floração, estratégias reprodutivas e polinização de espécies simpátridas do gênero Byrsonima Rich (Mapighiaceae). Rev. Bras. Biol. 52, 343-353

Buchmann, S.L. (1987) The ecology of oil flowers and their bees. Annu. Rev. Ecol. Syst. 18, 343-369

Chesson, P. (2000) Mechanisms of maintenance of species diversity. Annu. Rev. Ecol. Syst. 31, 343-366

Costa, C.B.N., Costa, J.A.S., Ramalho, M. (2006) Biologia reprodutiva de espécies simpátridas de Malpighiaceae em dunas costeiras da Bahia, Brasil. Rev. Bras. Bot. 29, 103-114

Davis, C.C., Bell, C.D., Mathews, S., Donoghue, M.J. (2002) Laurasian migration explain Gondwanan disjunctions: evidence from Malpighiaceae. Proc. Natl. Acad. Sci. U.S.A. 99, 6833-6837

Freitas, B.M., Alves, J.E., Brandão, G.F., Araújo, Z.B. (1999) Pollination requirements of West Indian cherry (Malpighia emarginata) and its putative pollinators, Centris bees, in NE Brazil. J. Agric. Sci. 133, 303-311

Gottsberger, G. (1986) Some pollination strategies in neotropical savannas and forests. Plant Syst Evol. 152, 29-45

Hanski, I. (1983) Coexistence of competitors in patchy environment. Ecology 64, 493-500

Hanski, I. (1999) Metapopulation ecology. Oxford University Press, New York

Joly, A.B. (1977) Botânica: Introdução à taxonomia vegetal. Editora Nacional, São Paulo

Machado, I.C. (2004) Oil-collecting bees and related plants: a review of studies in the last twenty years and case histories of plants occurring in NE Brasil. In: Freitas, B.M., Pereira, J.O.P. (eds.) Solitary Bees: Conservation, Rearing and Management for Pollination, pp. 255-281. Imprensa Universitária, Fortaleza

Mittelbach, G.G., Steiner, C.F., Scheiner, S.M., Gross, K. L., Reynolds, H.L., Waide, R.B., Willig, M.R., Dodson, S.I., Gough, L. (2001) What is the observed relationship between species richness and productivity? Ecology 82, 2381-2396 
Neff, J.L., Simpson, B.B. (1981) Oil-collecting structures in the Anthophoridae (Hymenoptera): morphology, function, and use in systematics. J. Kans. Entomol. Soc. 54, 95-123

Owen, J.G. (1988) On productivity as a predictor of rodent and carnivore diversity. Ecology 69, 11611165

Partel, M., Laanisto, L., Zobel, M. (2007) Contrasting plant productivity-diversity relationships across latitude: the role of evolutionary history. Ecology 88, 1091-1097

Ramalho, M., Silva, M. (2002) Flora Oleífera e sua Guilda de Abelhas em uma Comunidade de Restinga Tropical. Sitientibus 2, 34-43

Raw, A. (1979) Centris dirrhoda (Anthophoridae), the bee visiting West Indian cherry flowers (Malpighia puncifolia). Rev. Biol. Trop. 27, 203-205

Rêgo, M., Albuquerque, P. (2006) Polinização do Murici. EDUFMA, São Luís

Renner, S.S., Schaefer, H. (2010) The evolution and loss of oil-offering flowers: new insights from dated phylogenies for angiosperms and bees. Phil. Trans. R. Soc. B 365, 423-435

Rosenzweig, M.L., Abramsky, Z. (1993) How are diversity and productivity related? In: Ricklefs, R. E., Schluter, D. (eds.) Species Diversity in Ecological Communities: Historical and Geographical Perspectives, pp. 52-65. The University of Chicago Press, Chicago

Rosenzweig, M.L. (1995) Species diversity in space and time. Cambridge University Press, Cambridge

Roubik, D.W. (1989) Ecology and Natural History of Tropical Bees. Cambridge University Press, Cambridge

Sigrist, M.R., Sazima, M. (2004) Pollination and reproductive biology of twelve species of Neotropical Malpighiaceae: stigma morphology and its implication for breeding system. Ann. Bot. 94, 33-41

Silveira F.A., Melo. G.A.R., Almeida E.A.B. (2002) Abelhas brasileiras: sistemática e identificação, Fernando A. Silveira, Belo Horizonte
Simpson, B.B., Neff, J.L. (1981) Floral rewards: alternatives to pollen and nectar. Ann. Mo. Bot. Gard. 68, 301-322

Slatkin, M. (1974) Competition and regional coexistence. Ecology 55, 128-134

Steiner, K.E., Whitehead, V.B. (2002) Oil secretion and the pollination of Colpias mollis (Scrophulariaceae). Plant Syst Evol. 235, 55-66

Taylor, D.W., Crepet, W.L. (1987) Fossil floral evidence of Malpighiaceae and an early plant-pollinator relationship. Am. J. Bot. 74, 274-286

Teixeira, L.A.G., Machado, I.C. (2000) Sistema de polinização e reprodução de Byrsonima sericea DC (malpighiaceae). Acta Bot Bras. 14, 347-357

Tilman, D. (1993) Species richness of experimental productivity gradients: how important is colonization limitation? Ecology 74, 2179-2191

Tilman, D., Pacala, S. (1993) The maintenance of species richness in plant communities. In: Ricklefs, R.E., Schluter, D. (eds.) Species Diversity in Ecological Communities: Historical and Geographical Perspectives, pp. 13-25. The University of Chicago Press, Chicago

Vance, R.R. (1984) Interference competition and the coexistence of two competitors on a single limiting resource. Ecology 65, 1349-1357

Vogel, S. (1990) History of the Malpighiaceae in the light of pollination ecology. Mem. N. Y. Bot. Gard. 55, 130-142

Waide, R.B., Willig, M.R., Steiner, C.F., Mittelbach, G., Gough, L., Dodson, S.I., Juday, P., Parmenter, R. (1999) The relationship between productivity and species richness. Annu. Rev. Ecol. Syst. 30, 257300

Wright, D.H., Currie, D.J., Maurer, B.A. (1993) Energy supply and patterns of species richness on local and regional scales. In: Ricklefs, R.E., Schluter, D. (eds.) Species Diversity in Ecological Communities: Historical and Geographical Perspectives, pp. 66-76. The University of Chicago Press, Chicago 